\title{
Seasonality of calliphorid and sarcophagid flies across Canterbury arable farms requiring pollinators
}

\author{
B.G. Howlett ${ }^{1}$, M.M. Davidson ${ }^{1}$, D.E. Pattemore ${ }^{2}$, M.K. Walker ${ }^{1}$ and W.R. Nelson ${ }^{1}$ \\ ${ }^{1}$ The New Zealand Institute for Plant \& Food Research Limited, Private Bag 4704, \\ Christchurch Mail Centre, Christchurch 8140, New Zealand \\ ${ }^{2}$ The New Zealand Institute of Plant \& Food Research Ltd, Private Bag 3230 \\ Waikato Mail Centre, Hamilton 3240, New Zealand \\ Corresponding author: brad.howlett@plantandfood.co.nz
}

\begin{abstract}
Calliphorid and sarcophagid flies are common, widespread pollinators of vegetable and forage seed crops. Information regarding their seasonal occurrence on arable farms growing these crops may help predict their temporal effectiveness and flexibility as pollinators. Window intercept traps (12 per farm) were placed at the edges of crop paddocks across five arable farms in Canterbury for periods of 1-6 weeks from 2012 to 2015. Total trapping days for each season over the four years were: summer 128, autumn 92, winter 199 and spring 35. Flies from at least six species were commonly caught from spring to autumn. Mean farm insect counts found Calliphora vicina to be the most abundant species in spring (237.3), summer (89.1) and winter (3.2), while Oxysarcodexia varia (212.9) and Pollenia spp. (190.3) were most abundant in autumn. Their broad temporal abundance shows their potential to pollinate crops that flower at different times.
\end{abstract}

Keywords, annual crops, insect pollinators, diversity, abundance, trapping, Calliphoridae, Sarcophagidae

\section{INTRODUCTION}

Non-bee pollinators play a significant role as pollinators of a wide range of crops (Garibaldi et al. 2013; Rader et al. 2016), yet the role of individual species as pollinators remains poorly understood. In New Zealand, flies from the families Calliphoridae (predominantly blow flies but also cluster flies) and Sarcophagidae (flesh flies) are among the most common flower visitors of Canterbury vegetable seed crops, such as pak choi [Brassica rapa var. chinensis (L.) Hanelt], onion (Allium cepa L.) and carrot (Howlett et al. 2005, 2009, 2013; Rader et al. 2012; Foundation for Arable Research 2012). They are also among the few fly families where there is information available on their effectiveness as pollinators of vegetable seed crops (Rader et al. 2009; Foundation for Arable Research 2012; Howlett et al. 2011; Howlett 2012). Many of these species have simple lifecycles with larvae feeding on animal protein or dung (Heath \& Appleton 2000), and adults on nectar (Heath 1982), making them pollinators that can potentially be managed (Howlett 2012).

Calliphorid and sarcophagid flies may complement honey bee pollination by pollinating at times when honey bees are less active. For example, calliphorids can be more active under 
lower light intensity and temperature than honey bees, and their abundance on crops can be more evenly distributed throughout the day (Howlett et al. 2013). Unlike honey bees, however, they cannot be as easily deployed through controlled and rapid movement of colonies. Therefore, understanding their seasonal activity patterns will assist in predicting populations relative to crop flowering, and the timing of possible strategies to manipulate their numbers.

The seasonality of calliphorid and sarcophagid flies has previously been examined at pasture sites in the North Island (Henning et al. 2005) and the South Island (Barratt et al. 2001) to assess their potential in rabbit control as vectors of rabbit haemorrhagic disease (Barratt et al. 1998; 2001). At a grassland/gorse site near Himatangi (North Island), peak abundance of Calliphora vicina Robineau-Desvoidy; $C$. hilli Patton; Lucilia sericata Meigen; C. stygia Fabricius; Chrysomya rufifacies Macquart; Oxysarcodexia varia Walker occurred from November to May (Henning et al. 2005). Similar patterns were also observed in a study by Barratt et al. (2001) in the South Island at 12 pasture sites in Marlborough and Central Otago regions and the Mackenzie district. However, the study found variation in fly species' populations between months; for example, the abundance of L. sericata declined significantly during early autumn, whereas, O. varia abundance remained relatively high. Moreover, $O$. varia counts were higher in open pasture than in gorse bush (Henning et al. 2005) and were higher at pasture sites where cattle were present (Barratt et al. 2001), demonstrating that the type of farming system can influence the abundance of particular fly species.

To our knowledge, studies on the seasonality of these species on arable farms in the Canterbury region (South Island) have not been conducted, despite these farms growing a wide variety of annual forage and vegetable seed crops that benefit from insect pollination. To address the lack of knowledge on the seasonal abundance of these potentially important crop pollinators, window traps were placed on five arable farms in Canterbury to capture the calliphorid blow fly species $C$. vicina, C. stygia, C. quadrimaculata (Swedarius), L. sericata and the calliphorid cluster flies Pollenia spp., along with the sarcophagid flesh fly $O$. varia. The study was conducted over a 4-year period.

Table 1. Dates of window trapping and duration across five arable farms in Canterbury, New Zealand.

\begin{tabular}{|c|c|c|c|c|c|}
\hline \multirow{2}{*}{ Farm } & \multirow{2}{*}{ Location } & \multicolumn{4}{|c|}{ Trap start date (Number of days that trapping was carried out) } \\
\hline & & Spring & Summer & Autumn & Winter \\
\hline 1 & $\begin{array}{l}43^{\circ} 32^{\prime} \mathrm{S}, \\
172^{\circ} 04^{\prime} \mathrm{E}\end{array}$ & $\begin{array}{l}30 / 10 / 2012 \\
(14)\end{array}$ & $10 / 12 / 2012$ & $14 / 03 / 2013(14)$ & 02/07/2013 (37) \\
\hline \multirow[t]{2}{*}{2} & $\begin{array}{l}43^{\circ} 33^{\prime} \mathrm{S}, \\
171^{\circ} 40^{\prime} \mathrm{E}\end{array}$ & & $04 / 12 / 2013(14)$ & $12 / 03 / 2014$ & $30 / 06 / 2014(21)$ \\
\hline & & & $03 / 12 / 2014 \quad(7)$ & $10 / 03 / 2015$ (9) & $23 / 07 / 2015(15)$ \\
\hline \multirow[t]{2}{*}{3} & $\begin{array}{l}43^{\circ} 53^{\prime} \mathrm{S} \\
172^{\circ} 03^{\prime} \mathrm{E}\end{array}$ & & $03 / 12 / 2013(14)$ & $11 / 03 / 2014$ & $02 / 07 / 2014(20)$ \\
\hline & & & $04 / 12 / 2014 \quad(7)$ & 09/03/2015 (9) & $22 / 07 / 2015(15)$ \\
\hline \multirow[t]{2}{*}{4} & $\begin{array}{l}43^{\circ} 53^{\prime} \mathrm{S} \\
171^{\circ} 51^{\prime} \mathrm{E}\end{array}$ & $\begin{array}{l}29 / 10 / 2012 \\
(14)\end{array}$ & $03 / 12 / 2013(14)$ & $11 / 03 / 2014$ & $02 / 07 / 2014(20)$ \\
\hline & & & $04 / 12 / 2014 \quad(7)$ & 09/03/2015 (9) & $22 / 07 / 2015$ (15) \\
\hline \multirow[t]{3}{*}{5} & $\begin{array}{l}43^{\circ} 54^{\prime} \mathrm{S}, \\
172^{\circ} 07^{\prime} \mathrm{E}\end{array}$ & $\begin{array}{l}28 / 10 / 2012 \\
(15)\end{array}$ & $10 / 12 / 2012$ & $13 / 03 / 2013(14)$ & $01 / 07 / 2013(21)$ \\
\hline & & & $03 / 12 / 2013(14)$ & $11 / 03 / 2014$ & $02 / 07 / 2014(20)$ \\
\hline & & & $03 / 12 / 2014 \quad(7)$ & $09 / 03 / 2015$ & $22 / 07 / 2015(15)$ \\
\hline
\end{tabular}



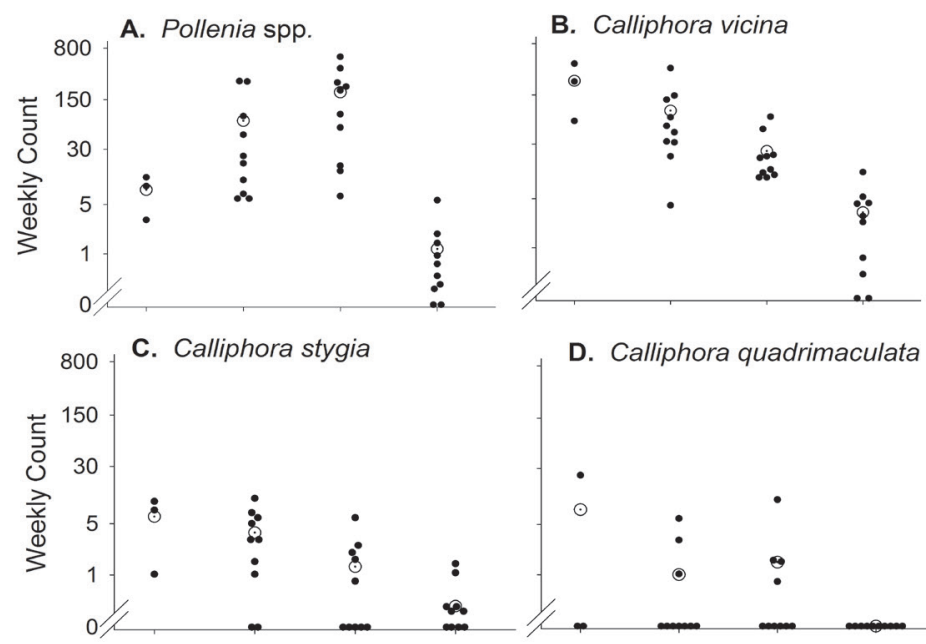

D. Calliphora quadrimaculata

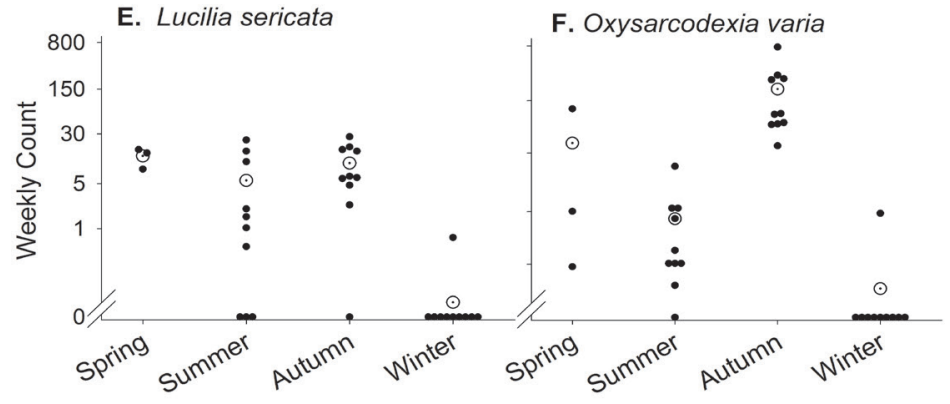

Figure 1. Weekly counts from arable farms across seasons for calliphorid (A-E) and sarcophagid (F) fly species. Each black circle is a total count from each of the 12 window traps on a single farm for a single trapping period, large clear circles are mean counts across trapping periods and farms. Y axis is log scale (common).

\section{MATERIALS AND METHODS}

Window intercept traps were placed intermittently for 7 to 37 days across five arable farms over consecutive years from 2013 and 2015. Trapping was conducted across all four seasons. The location of farms, trapping periods and number of days trapped are listed in Table 1. Twelve traps were placed on each farm during each trapping period. Each trap consisted of a 6-L yellow tray that held two perpendicular Perspex windows. They were secured above the ground on a green bucket using string tied over the Perspex windows onto garden stakes positioned around the four sides of the trap. Further details of the survey design, including within farm trap placements and trap design, specimen collection and examination are provided by Davidson et al. (2015).

The seasonal occurrence and relative abundance of each species was evaluated using the number of flies captured per week to allow for variation in the length of each trapping period.

\section{RESULTS}

A total of 6185 calliphorid and 3651 sarcophagid flies were counted across all trapping periods and all farms. Four calliphorid and one sarcophagid 
species were identified to this level, while another calliporid, Pollenia was recorded at the level of genus.

Of the calliphorid flies, Pollenia spp. were the most abundant overall, at $53.4 \%$, followed by $C$. vicina at $39.7 \%$. The remaining species were L. sericata $4.5 \%$; C. stygia $1.6 \%$ and C. quadrimaculata $0.9 \%$. However, there was variation in their relative abundance among farms. Pollenia spp. counts were very high on farm 2 [81.6\% $(n=1023)]$ but relatively low on farm 1 [14.3\% $(\mathrm{n}=137)]$. On farm 1, C. vicina was the most abundant species [80.5\% $(n=772)]$. The number of all other calliphorid species trapped across farms was relatively low (less than 11\%). All sarcophagids trapped were $O$. varia. The highest counts of this species was recorded from farm 5 $(n=2102)$ and the lowest from farm $2(n=188)$.

Generally, fewer than five individuals of any species were captured per week during the winter (Figure 1A-F). However, the weekly counts varied among species across the other three seasons. Weekly counts of Pollenia spp. were highest in autumn (mean $=190.3 /$ farm) and summer (mean $=75.3 /$ farm $)$ (Figure $1 \mathrm{~A}$ ). C vicina counts were, on average, highest in spring (mean $=6.2 /$ farm $)$, declining through summer $($ mean $=3.8 /$ farm $)$ and autumn (mean $=1.3 /$ farm) (Figure 1B). C. stygia and C. quadrimaculata counts were low (mostly $<5$ per trap per week) throughout all trapping periods (Figures 1C, D), but the data suggest similar trends among seasons to those of C. vicina (Figure 1B). L. sericata counts remained similar from spring (mean 13.5/farm) to autumn (mean 10.4/farm) (Figure 1E), while $O$. varia counts were highest in autumn (mean 212.9/farm) (Figure 1F). C. vicina (Figure 1B) was the most commonly captured species during winter, followed by Pollenia spp. (Figure 1A).

\section{DISCUSSION}

Spring and summer are critical periods for seed crops that benefit from insect pollination for increased yield. At least five calliphorid species and one species of sarcophagid were frequently captured by window traps placed on Canterbury arable farms from spring to autumn, indicating their potential value as pollinators of a range of flowering crops. This includes spring flowering (September-October) forage brassica crop (such as B. rapa L., B. napus L., B. oleracea L.) cultivars (Stewart 2002), and summer flowering (December-January) vegetable seed crops such as pak choi (B. rapa ssp. chinensis), carrot [Daucus carota subsp. sativus (Hoffm) Arcang], onion and radish (Raphanus sativus L.).

The trends reported in the present study indicated that some fly species, such as Pollenia spp., became increasingly active over spring and summer, to reach a peak in flight activity by autumn. Other species, such as C. vicina, exhibited the opposite trend. However, the relative abundance of Pollenia spp. and C. vicina in traps in summer were similar, so it may be that both species could contribute equally to pollination of summer-flowering crops. In contrast, $O$. varia numbers peaked in autumn, after the flowering time of key vegetable seed crops.

Despite this study providing insights on how fly activity patterns might relate to the timing of crop flowering, detailed analysis was limited by the nature of the data collection. To date, the data have predominantly been collected within specific months within each season, i.e. OctoberNovember (spring), December (summer), March (autumn) and June-July (winter). Peaks and troughs in fly activity may have been missed during the other months. Moreover, this study did not consider how within-farm landscape or weather may affect patterns of fly activity and distribution. These factors have are known to influence the abundance of most of these fly species (Barratt et al. 2001; Henning et al. 2005). The relationship between trap counts and fly activity on actual crops was not conducted in this study. However, Howlett et al. (2009) did find correlations between window trap versus direct observation counts within peak flowering onion and pak choi crops.

Further consideration also needs to be given to other beneficial and negative impacts that these flies can have in agricultural landscapes. Blow and flesh flies are considered useful vectors of rabbit haemorrhagic disease virus to control rabbits 
(Barratt et al. 1998; 2001). However, some of the species are also primarily responsible for sheep fly-strike (cutaneous myiasis). In New Zealand, L. sericata and L. cuprina are considered the most problematic species, although C. stygia is also a primary fly-strike species (Morris 2005). C. vicina and C. quadrimaculata, are considered to be very minor contributors to fly-strike (Heath \& Bishop 1995). L. sericata and C. stygia were present in relatively low numbers in this study (Figure 1); however, counts from the flowers of arable crops across farms in Canterbury and elsewhere in New Zealand indicate they are often amongst the most common flower visiting species (Howlett et al. 2013). Careful selection of diet types favourable to specific species (Heath \& Appleby 2000) may offer the potential to manipulate populations of more desirable species rather than problematic species.

\section{ACKNOWLEDGEMENTS}

We wish to thank the Foundation for Arable Research for supporting this research; the farmers John Evans, Paul Jarman, Ian Marr, David Ward; and Midland Seeds for access to their properties. Thanks to Sam Read, Stacey Skill, Joep van Cranenbroek, Mathilde Dusart, Fanny LeBarbier, Pim Lemmers, Rachael L'helgoualc'h, Alexandre Benoist, Simon Cornut, Murielle Cuenin, Thomas Besnier, Philomene Brunelliere, Lise Bertrand and Hélène Le Chenedec for their assistance with the sampling at the Canterbury farms. This work was in part funded by a MBIE C11X1309 Bee Minus to Bee Plus and Beyond: Higher Yields From Smarter, Growth-focused Pollination Systems, MPI Sustainable Farming Fund project (12-015, Building Better Biodiversity on Cropping Farms) and The New Zealand Institute for Plant \& Food Research Limited.

\section{REFERENCES}

Barratt BIP, Ferguson CM, Heath ACG, Logan RAS 2001. Relative abundance and seasonality of Calliphoridae and Sarcophagidae (Diptera), potential vectors of rabbit haemorrhagic disease virus (RHDV) in the South Island of New Zealand. New Zealand Journal of Zoology 28(4): 417-428.

Barratt BIP, Ferguson CM, Heath ACG, Evans AA, Logan RAS 1998. Can insects transmit rabbit haemorrhagic disease virus? Proceedings of the Fifty First New Zealand Plant Protection Conference, Quality Hotel, Hamilton, New Zealand, 11-13 August, 1998: 245-250.

Davidson MM, Howlett BG, Butler RC, Taylor NM, Walker MK 2015. The influence of shelterbelts in arable farmland on beneficial and pest invertebrates. New Zealand Plant Protection 68: 367-372.

Foundation for Arable Research 2012. Crop Pollination, FAR focus, Issue 7. http:// www.far.org.nz/mm_uploads/25801_FAR_ focus_7_-_crop_pollination.pdf. Pp. 53.

Garibaldi LA, Steffan-Dewenter I, Winfree R, Aizen MA, Bommarco R, Cunningham SA, Kremen C, Carvalheiro LG, Harder LD, Afik $\mathrm{O}$ and others 2013. Wild pollinators enhance fruit set of crops regardless of honey-bee abundance. Science 339: 1608-1611.

Heath ACG 1982. Beneficial aspects of blowflies (Diptera: Calliphoridae). New Zealand Entomologist 7: 343-348.

Heath ACG, Appleton C 2000. Small vertebrate carrion and its use by blowflies (Calliphoridae) causing ovine myiasis (flystrike) in New Zealand. New Zealand Entomologist 22: 81-87.

Heath ACG, Bishop DM 1995. Flystrike in New Zealand. Surveillance 22: 11-13.

Henning J, Schnitzler FR, Pfeiffer DU, Davies $P$ 2005. Influence of weather conditions on fly abundance and its implications for transmission of rabbit haemorrhagic disease virus in the North Island of New Zealand. Medical and Veterinary Entomology 19(3): 251-262.

Howlett B, Butler R, Nelson W, Donovan B 2013. Impact of climate change on crop pollinator activity in New Zealand. MPI Technical Paper No: 2013/30, Ministry for Primary Industries. 45 pp. www.mpi.govt.nz/ document-vault/4101.

Howlett BG 2012. Hybrid carrot seed crop 
pollination by the fly Calliphora vicina (Diptera: Calliphoridae). Journal of Applied Entomology 136: 421-430.

Howlett BG, Donovan BJ, McCallum JA, Newstrom LE, Teulon DAJ 2005. Between and within field variability of New Zealand Indigenous Flower Visitors to Onions. New Zealand Plant Protection 58: 213-218.

Howlett BG, Walker MK, Newstrom-Lloyd LE, Donovan BJ, Teulon DAJ 2009. Window traps and direct observations record similar arthropod flower visitor assemblages in two mass flowering crops. Journal of Applied Entomology 133: 553-564.

Howlett BG, Walker MK, Rader R, Butler RC, Newstrom-Lloyd LE, Teulon DAJ 2011. Can insect body pollen counts be used to estimate pollen deposition on pak choi stigmas? New Zealand Plant Protection 64: 25-31.

Morris MC 2005. Tests on a new bait for flies (Diptera: Calliphoridae) causing cutaneous myiasis (flystrike) in sheep. New Zealand Journal of Agricultural Science 48: 151-156.
Rader R, Howlett B, Cunningham S, Westcott D, Newstrom-Lloyd L, Walker M, Teulon D, Edwards W 2009. Alternative pollinator taxa are equally efficient, but not as effective as the honeybee in a mass flowering crop. Journal of Applied Ecology 46: 1080-1087.

Rader R, Howlett BG, Cunningham SA, Westcott DA, Edwards W 2012. Spatial and temporal variation in pollinator effectiveness: do unmanaged insects provide consistent pollination services to mass flowering crops? Journal of Applied Ecology 49(1): 126-134.

Rader R, Bartomeus I, Garibaldi LA, Garratt MPD, Howlett BG, Winfree R, Cunningham SA, Mayfield MM, Arthur AD, Andersson GKS and others 2016. Non-bee insects are important contributors to global crop pollination. Proceedings of the National Academy of Sciences of the United States of America 113(1): 146-151.

Stewart AV 2002. A review of Brassica species, cross-pollination and implications for pure seed production in New Zealand. Agronomy New Zealand, 32/33, 63-82. 